\title{
Do Landscape Structure and Socio-Economic Variables Explain the Solidago Invasion?
}

\author{
Magdalena Szymura • Tomasz H. Szymura • \\ Sebastian Świerszcz
}

Received: 9 January 2015 / Accepted: 3 March 2016/Published online: 19 April 2016

(C) The Author(s) 2016. This article is published with open access at Springerlink.com

\begin{abstract}
Biological invasions are considered a major threat to biodiversity on a global scale. In this study, we examined the effect of landscape structure and socioeconomic variables on the invasion pattern of alien Solidago species. Field data were collected in a set of 309 sampling plots, regularly placed on the intersecting lines of a $10 \times 10-\mathrm{km}$ grid, in south-western Poland (Silesia, Central Europe). Landscape characteristics and average values of socio-economic variables, such as human population density and total income per capita, were calculated. To examine the effect of landscape structure across different spatial extents, the landscape characteristics were analysed for three different buffers (radius: $500 \mathrm{~m}, 2 \mathrm{~km}$ and $5 \mathrm{~km}$ ). A model explaining the pattern of the invasion was developed using a univariate, binary classification (decision) tree. The results show that both landscape structure and density of human population explain the spatial pattern of the invasion by alien Solidago species. The pattern was
\end{abstract}

Electronic supplementary material The online version of this article (doi:10.1007/s12224-016-9241-4) contains supplementary material, which is available to authorized users.

M. Szymura $(\bowtie) \cdot S$. Świerszcz

Department of Agroecosystems and Green Areas Management, Wrocław University of Environmental and Life Sciences, Pl. Grunwaldzki 24A, 50-363 Wrocław, Poland

e-mail: magdalena.szymura@up.wroc.pl

T. H. Szymura

Department of Ecology, Biogeochemistry and Environmental Protection, University of Wrocław, Kanonia 6/8, 50-328 Wrocław, Poland mostly shaped by the presence of unsuitable (forests) and suitable (roadsides) habitats for Solidago. The influence of percentage forest cover and road length was the strongest at the small spatial extent (radius $=500 \mathrm{~m}$ ). The sum of linear elements length, percentage of urban areas and human population density calculated at the large extent (radius $=5 \mathrm{~km}$ ) significantly improved the model. However, the predictive ability of these variables was less accurate. The model can be used by local authorities and land managers for modelling/predicting the hazards of invasion and elaborating a landscapelevel system of Solidago control.

Keywords land cover · land use - regional scale . multiple spatial scales $\cdot$ invasion modelling $\cdot$ biological invasions

\section{Introduction}

Biological invasions alter biodiversity levels, landscape structure, ecosystem functions and services, local economy, and human health and well-being (Pejchar and Mooney 2009; Pyšek and Richardson 2010; Vilà et al. 2011). They are considered a component of global changes challenging the conservation of biodiversity and natural resources (Simberloff et al. 2013). The successful management of biological invasions relies on understanding the mechanism behind the invasion process (González-Moreno et al. 2014).

Plant invasions are regarded as extremely complex processes (Santos et al. 2011). They are affected by 
multiple interacting factors including abiotic conditions, human activity and habitat type, which may operate at different spatial scales (Kumar et al. 2006; Pauchard and Shea 2006; Catford et al. 2009; Milbau et al. 2009; Vicente et al. 2010, 2014; González-Moreno et al. 2014). Nevertheless, they can be described and understood using different kinds of simplified models. At a very broad scale (continental, globe), climate is the most important single factor determining the risk of invasion (Thuiller et al. 2005; Milbau et al. 2009). At the regional scale, however, considerable variation between habitats in the number of alien species that they harbour has been observed (Chytrý et al. 2005, 2008a,b; Thiele et al. 2009; Chmura et al. 2013; González-Moreno et al. 2014). Such differences are explained by (a) variation between ecological requirements of alien species and the available niches in the invaded area and (b) differences in the inherent susceptibility of habitats to invasion (Lonsdale 1999; Brabec and Pyšek 2000; Shea and Chesson 2002; Chytrý et al. 2008a,b; Fukami et al. 2013).

Another factor shaping the number of alien species at a given site is propagule pressure, which is the rate of influx of alien propagules into the site (Lonsdale 1999; Eriksson 2000; Lockwood et al. 2005; Sîrbu et al. 2012). Propagule pressure is difficult to quantify at the regional scale, particularly for multispecies assemblages; therefore, some proxy has been used (Ozinga et al. 2005; Chytrý et al. 2008a,b, 2009). These proxies could be socio-economic variables (e.g. human population density, intensity of traffic or trade) as well as indicators of human wealth or landscape characteristics (Pino et al. 2005; Westphal et al. 2008; Thiele et al. 2009; Hulme 2009; Pyšek et al. 2010; Santos et al. 2011). Some habitats, such as road verges, river corridors and human settlements, are exposed to stronger propagule pressure than other habitats (Lonsdale 1999; Wasiłowska 1999; Otto et al. 2014). Thus, they are also used as a proxy of influx of alien species propagules (Chytrý et al. 2008a,b; Jørgensen and Kollmann 2009). Numerous studies have shown that the presence of habitat edges enhance plant invasions. They possibly provide a high amount of light and nutrients as well as increase plant dispersal (Pauchard and Alaback 2006; Vilà and Ibáñez 2011). It has also been observed that diverse landscapes support a higher number of alien species than more homogeneous ones (Deutschewitz et al. 2003; Pino et al. 2005; Kumar et al. 2006). Therefore, for modelling purposes, different characteristics of landscape diversity and habitat edges have usually been employed (e.g. Deutschewitz et al. 2003; Ohlemüller et al. 2006; Bartuszevige et al. 2006; Ibáñez et al. 2009b; Vicente et al. 2010, 2014; Catford et al. 2011; González-Moreno et al. 2013, 2014).

Land use/land cover (LU/LC) data and other metrics of landscape structure as well as socio-economic variables have been successfully used for modelling plant invasions both at the community (Ibáñez et al. 2009b; Matthews et al. 2009; Catford et al. 2011; GonzálezMoreno et al. 2013; Basnou et al. 2015) and species level (Bradley and Mustard 2006; Bartuszevige et al. 2006; Ibáñez et al. 2009a,b; Marcer et al. 2012). However, the influence of these factors on plant invasions varies in relation to spatial extent (i.e. buffer area from the focal sampling unit) in which they were measured (Bartuszevige et al. 2006; Kumar et al. 2006; GonzálezMoreno et al. 2013; Basnou et al. 2015). Therefore, different extents have been explored in order to find the most influential extent (Kumar et al. 2006; Ohlemüller et al. 2006; González-Moreno et al. 2013; Basnou et al. 2015), or the extent was selected on the basis of some pre-existing knowledge about the mechanisms underlying the invasion (Bartuszevige et al. 2006; Matthews et al. 2009).

Members of the genus Solidago are exceptionally successful worldwide invaders from North America (Pyšek 1998; Semple and Cook 2006; Weber and Jacobs 2005). About 120 Solidago species are known from the native range, among which three are invaders that, so far, have conquered Europe, large parts of Asia, Australia and New Zealand. The invasion of Solidago species in Europe has been observed for many years (TokarskaGuzik 2001). Nowadays, they occupy vast areas and are considered among the most successful invaders of Europe (Weber 1998, 2001; Pyšek et al. 2002; Scharfy et al. 2009). In Central Europe, three exotic representatives of the Solidago genus are naturalized: smooth goldenrod, S. gigantea Aiton, Canadian goldenrod, S. canadensis s.1. L., and grass-leaved goldenrod, S. graminifolia (L.) Elliott [= Euthamia graminifolia (L.) Nutt.]. Two introduced taxa, S. gigantea and S. canadensis s.l., are widely distributed in Europe, while the range of $S$. graminifolia is small and limited to a few locations (Weber 2001; Dajdok and Nowak 2006; Kompała-Baba and Bąba 2006). Invasive species of Solidago are able to better utilize resources for biomass production than co-occurring plant species native to Central Europe (Szymura and Szymura 2015). The 
increase of the cover of alien Solidago species in patches of vegetation is correlated with a decrease in species richness (Hejda et al. 2009; Del Fabbro et al. 2013; Fenesi et al. 2015) and alters spontaneous succession (Bornkamm 2007; Bartha et al. 2014). Meadows, invaded by goldenrods, have lower bird species richness and lower numbers of breeding pairs than uninvaded ones (Skórka et al. 2010). The invasion of Solidago also caused a decrease in the abundance, species richness and diversity of pollinators: wild bees, hoverflies and butterflies (Moroń et al. 2009, but see also Fenesi et al. 2015). The increase of the area covered by alien goldenrods reduces visitation of native flowers by pollinators (Fenesi et al. 2015). Moreover, their presence alters the biogeochemical cycles and primary productivity of invaded habitats (Vanderhoeven et al. 2005, 2006; Chapuis-Lardy et al. 2006; Scharfy et al. 2010). In the case of the two most common species, S. canadensis and $S$. gigantea, their population number and size have to be controlled in Europe (Sheppard et al. 2006; Fenesi et al. 2015).

Due to their high environmental impact, wide range of distribution and locally high abundance, invasive Solidago species have been the subjects of numerous studies focusing on their biology, ecology and environmental impact. Nonetheless, the spatial pattern of the Solidago invasion has never been examined in the context of the effect of landscape structure and socioeconomic variables. Previous studies on alien goldenrod distribution were focused on the effect of climate on their range in Europe. The results reveal that further extension of their range should be expected (Weber 2001). It is stated that the eradication of invasive species with a large area of infestation seems to be impossible; however, their population number and size can still be effectively controlled (Hulme 2009; Pyšek and Richardson 2008). Knowledge about the control of invasive Solidago species pertains to their local eradication from certain patches of vegetation (Weber 2000; Weber and Jacobs 2005; Horváth 2012). However, successful strategies for reducing populations of alien species should also be planned at the landscape level (Vilà and Ibáñez 2011; Basnou et al. 2015). For this purpose, knowledge about the mechanisms of invasion operating at landscape scale is required (Vilà and Ibáñez 2011; González-Moreno et al. 2014). In this study, we examined the effect of landscape characteristics and socioeconomic variables on the pattern of invasion by alien Solidago species in the area of south-western Poland
(Silesia, Central Europe). We hypothesized that landscape structure, socio-economic variables or both explain the pattern of invasion by alien Solidago species in the study region. In our study, we aimed to establish the relationship between the examined variables and the distribution of invasive Solidago species as well as to reveal to the spatial extent at which the impact of each particular variable is the most pronounced.

\section{Material and Methods}

\section{Study Species}

Three alien Solidago species ( $S$. canadensis s.1., S. gigantea and S. graminifolia), belonging to the Asteraceae family, were examined. The plants are perennial herbs with a rhizome. Their stems are single up to the inflorescence, and non-flowering leaf rosettes are often present. There are discrepancies in the taxonomic status of the taxa under study. Solidago graminifolia is easily distinguishable from the others on the basis of narrow leaves and flat-topped inflorescences. In America, this species is referred to as Euthamia graminifolia (L.) Nutt. on the basis of anatomy and DNA studies (Semple et al. 1981; Semple et al 1984; Abrahamson et al. 2005). The remaining taxa are morphologically similar to each other. They are higher and have wider leaves than $S$. graminifolia; moreover, their inflorescences are a fasciculate, thyrsoid panicle. Solidago gigantea is distinguished by a glabrous, purplish stem covered with wax and glabrous leaves (Semple and Cook 2006; Abrahamson et al. 2005). Taxa with hairy stems and leaves are more often referred to as S. canadensis s.1., a complex taxon with two varieties: canadensis and scabra (Guzikowa and Maycock 1986; Weber 1997; Weber and Schmid 1998). In some publications, however, they are treated as separate species: S. canadensis and S. altissima (e.g. Rutkowski 2013; Rothmaler 2007). Moreover, plants described as S. altissima in Europe have more traits similar to the American taxon S. canadensis var. hargeri Fern. than to American individuals of S. altissima (John Semple, personal information). However, the taxa differ in their rhizome systems (Schmid et al. 1988), as well as in micro-morphological features of the leaf epidermis (Szymura and Wolski 2011).

Alien Solidago species occur in soils with a wide range of fertility and moisture levels. They create single- 
species stands or co-occur with each other (Weber 2001; Weber and Jacobs 2005). Long-range dispersal is realized by numerous wind-dispersed seeds whereas shortrange spread is realized by vegetative growth of rhizomes (Weber 2001). They can create large stands in abandoned fields and meadows, riparian habitats, forest edges and unmowed road verges (Weber 2001; Weber and Jacobs 2005; Szymura and Szymura 2011, 2013; Bartha et al. 2014; Fenesi et al. 2015). The alien Solidago species included in this study are similar with respect to their biology and ecology, and they do not differ in their habitat preferences and soil conditions in the study region. Moreover, their ranges within the study region overlap each other, and the species can co-occur at single sites (Szymura and Szymura 2011, 2013). We therefore decided to establish one model for all of the taxa under study.

\section{Field Data}

The study was performed in the Polish part of the Silesia region (south-western Poland, Central Europe), with an area of approximately $32,000 \mathrm{~km}^{2}$. The main city of the region is Wrocław (Fig. 1). The study region mostly consists of lowlands and a in rather small part of foothills and mountains. The elevation of the study plots ranged from 50 to up to $1,100 \mathrm{~m}$ a.s.l., but most of the plots (75\%) were located at 100-300 $\mathrm{m}$ a.s.l. According to the climatic data of Hijmans et al. (2005), the total annual precipitation varied between 533 and $858 \mathrm{~mm}$ (mostly $550-650 \mathrm{~mm}$ ), and the average annual temperature varied between $3.5^{\circ} \mathrm{C}$ and $9.2^{\circ} \mathrm{C}(75 \%$ of plots in the range $7.4^{\circ} \mathrm{C}-8.6^{\circ} \mathrm{C}$ ). The land mostly serves agricultural (approximately $64 \%$ ) and forestry (approximately $28 \%$ ) purposes. The average human population density is about 135 persons per square kilometre and varies from 17 to 2,011 persons per square kilometre. In the study region, as in other Central European countries where a shift from a socialistic planning system to market economy occurred, there have been tendencies towards agricultural intensification in some areas and to land abandonment in others (Orłowski 2005; Stoate et al. 2009).

The field data were collected in a set of 309 sampling plots regularly placed in nodes of a $10 \times 10 \mathrm{~km}$ grid (Fig. 1). Each sampling plot covered 25 ha (radius 282 $\mathrm{m})$, and all plots were visited and examined for the presence of alien Solidago species. Subsequently, the plots were classified as follows: (1) Solidago-uninvaded - without the presence of any of the four target species and (2) Solidago-invaded - plots where at least one of

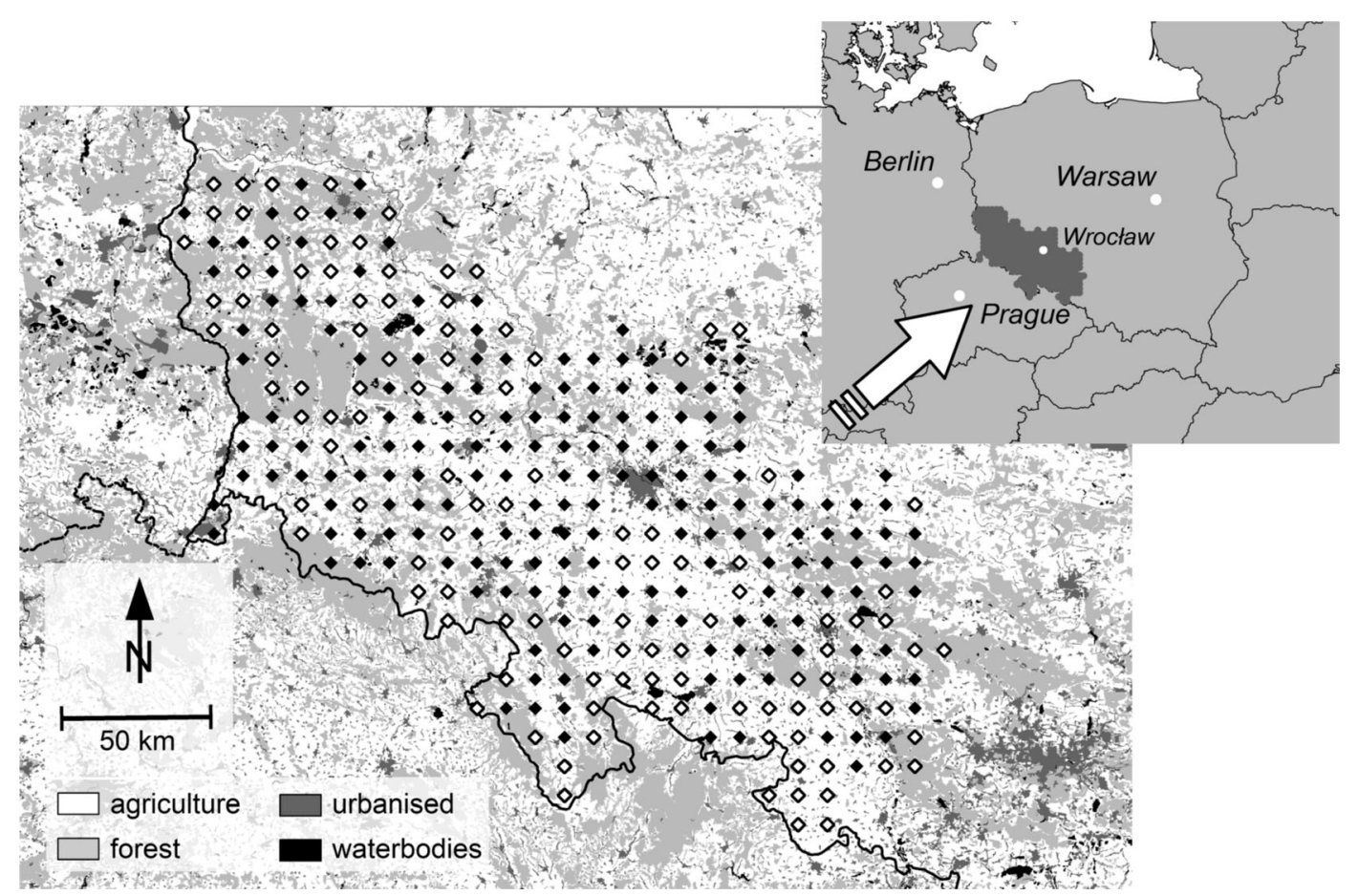

Fig. 1 Locations of study plots invaded (black diamonds) and uninvaded (white diamonds) by alien Solidago species. In the background: land use/land cover (lower panel) and location of the study region (dark grey, upper panel). 
the target species was found, irrespective of its abundance. Field studies were conducted between May and September in 2010 and 2011. The minimal time spent on each plot differed depending on the ability to find an alien Solidago population. As a rule, we spent $45 \mathrm{~min}$ for exploring the plot, until we accepted lack of the invasive Solidago species. The examined populations were found on abandoned land (38\%), road verges (33\%), margins of different kinds of habitats (12\%), along watercourses $(7 \%)$, and in meadows $(6 \%)$, forests $(2 \%)$ and shrub communities $(2 \%)$.

\section{Landscape Data and Socio-Economic Variables}

We selected several landscape characteristics and socioeconomic variables that are commonly associated with plant invasion and/or seem to be useful considering the biology and ecology of the examined alien Solidago species. A detailed list of these explanatory variables and the rationales for their use is presented in Table 1.

\section{Landscape Data}

The land use/land cover data (LU/LC) data were derived from the Corine 2006 map, which shows 44 classes of LU/ $\mathrm{LC}$ as rasters with a $100 \times 100 \mathrm{~m}$ spatial resolution (Bossard et al. 2000; Büttner and Maucha 2006). The original Corine LU/LC classification was simplified into four classes: urbanized areas (urban), waterbodies, agricultural areas (agriculture) and forests. The following landscape metrics were calculated: percentage of given LU/LC, number of LU/LC classes per plot, number of patches, Shannon index of landscape diversity $\left(\mathrm{H}^{\prime}\right)$ and total edge length (sum of lengths of boundaries between patches).

Information about linear elements: (1) railways, (2) roads and (3) watercourses was obtained from OpenStreetMap (Geofabrik GmbH and OpenStreetMap Contributors 2014). The sum of the lengths of the given linear elements (length of roads, railways and watercourses) and the sum of all the lengths of the linear elements (sum of linear elements length) were calculated.

To examine the effect of landscape structure across different spatial extents, the landscape characteristics were calculated for three different buffers (Fig. 2). The large extent includes characteristics calculated for a circular buffer placed around the centre of each sampling plot with a 5-km radius (approximately 7,700 ha). The medium and small extent include the characteristics calculated for a buffer with a $2-\mathrm{km}$ radius (approximately 1,200 ha) and 0.5-km radius (approximately $77 \mathrm{ha}$ ), respectively.

\section{Socio-Economic Variables}

Data on human population density and total per capita income were obtained from the Central Statistical Office of Poland. These socio-economic variables were related to the basic administrative units of Poland called gmina. In the study area, there were 297 of these units, with an average size of approximately $70 \mathrm{~km}^{2}$. The average human population density was expressed as the number of inhabitants per square kilometre $\left(N / \mathrm{km}^{2}\right)$, while income was expressed as Polish złoty (PLN) per capita. Due to the fact that the areas of the buffers did not overlap with the area of a particular gmina, weighted average values of these socio-economic variables were calculated, where the weight was proportional to the area of a given gmina in an analysed buffer.

\section{Statistical Analysis}

We used a univariate, binary classification (decision) tree to determine which landscape characteristics and socioeconomic variables explained the presence of Solidago species. The classification tree was constructed using the Classification and Regression Tree (CART) algorithm (Breiman et al. 1984). The purpose of the analyses was to determine a set of 'if-then' logical conditions (splits) that enable accurate characterization of 'Solidago-invaded' or 'Solidago-uninvaded' plots. Splits placed close to the tree root (i.e. the initial splits) give a higher accuracy of classification than farther splits. The tree is hierarchical; that is, the final splits depends on the decisions undertaken in the previous (placed close to tree root) splits. There is no implicit assumption that the underlying relationships between the predictor variables and the dependent variables are linear, follow some specific non-linear link function, or are even monotonic in nature. Moreover, the same variable can be used in a few splits if it gives the best accuracy of classification. For assessing node purity (i.e. the accuracy of prediction in a given node), we used the Gini coefficient. The optimal tree size was determined using V-fold cross-validation with 1 S.D. rule (Breiman et al. 1984; Ripley 1996). To summarize the tree, a misclassification rate was used, that is, the percentage of wrong classification. The misclassification rate can be compared with the proportion of absences in 
Table 1 Examined socio-economic variables and landscape characteristics (explanatory variables) used as predictors in the model of alien Solidago invasion, their ecological rationale and corresponding data sources.

\begin{tabular}{|c|c|c|}
\hline Explanatory variables & Rationale & Data source \\
\hline \multicolumn{3}{|l|}{ Socio-economic variables: } \\
\hline $\begin{array}{l}\text { Income }[\mathrm{PLN}] \\
\text { Human population density }\left[N / \mathrm{km}^{2}\right]\end{array}$ & $\begin{array}{l}\text { proxy of propagule pressure and } \\
\text { fraction of human-influenced } \\
\text { habitats }^{1-4}\end{array}$ & $\begin{array}{l}\text { Central Statistical } \\
\text { Office of Poland }\end{array}$ \\
\hline \multicolumn{3}{|l|}{ Landscape characteristics: } \\
\hline & $\begin{array}{l}\text { land use/land cover (LU/LC) types } \\
\text { and its derivatives }\end{array}$ & \\
\hline$\%$ urban & $\begin{array}{l}\text { proxy of propagule pressure and } \\
\text { fraction of human-influenced } \\
\text { habitats }\end{array}$ & $\begin{array}{l}\text { Corine } 2006 \\
\text { LU/LC map }\end{array}$ \\
\hline$\%$ water bodies & habitat unsuitable for Solidago species ${ }^{5,6}$ & \\
\hline$\%$ agriculture & $\begin{array}{l}\text { Solidago species are fragile to regular } \\
\text { mowing and herbicides }{ }^{5-7} \text {, agriculture } \\
\text { as a barrier for plant invasion }{ }^{8-10}\end{array}$ & \\
\hline$\%$ forest & $\begin{array}{l}\text { habitat unsuitable for Solidago species, } \\
\text { since they are considered as light demanding } \\
5,6\end{array}$ & \\
\hline $\begin{array}{l}\text { Number of LU/LC class } \\
\mathrm{H}^{\prime} \\
\text { Number of patches } \\
\text { Total edge length }[\mathrm{km}]\end{array}$ & \multirow[t]{2}{*}{$\begin{array}{l}\text { Solidago species often occur on habitat edges } \\
\text { Landscape diversity and edges amount are } \\
\text { generally correlated with } \\
\text { alien species richness }{ }^{11-13}\end{array}$} & \\
\hline Linear elements in landscape & & \\
\hline Length of roads $[\mathrm{km}]$ & $\begin{array}{l}\text { proxy of propagule pressure and human-influenced } \\
\text { areas }{ }^{1,2} \text {, roadsides could serve as suitable habitats } \\
\text { for invasive species }{ }^{13-16}\end{array}$ & OpenStreet Map \\
\hline Length of railways $[\mathrm{km}]$ & proxy of propagule pressure and human-influenced areas ${ }^{2}$ & \\
\hline Length of watercourses $[\mathrm{km}]$ & $\begin{array}{l}\text { riversides are considered as suitable habitats for Solidago } o^{5,6} \\
\text { proxy of propagule pressure } \\
2,17\end{array}$ & \\
\hline Sum of linear elements length $[\mathrm{km}]$ & proxy of propagule pressure ${ }^{2,14}$ & \\
\hline
\end{tabular}

${ }^{1}$ Westphal et al. 2008; ${ }^{2}$ Hulme 2009; ${ }^{3}$ Pyšek et al. 2010; ${ }^{4}$ Santos et al. 2011; ${ }^{5}$ Weber 2000; ${ }^{6}$ Weber and Jacobs 2005; ${ }^{7}$ Domaradzki and Badowski 2012; ${ }^{8}$ Wania et al. 2006; ${ }^{9}$ González-Moreno et al. 2013; ${ }^{10}$ Basnou et al. 2015; ${ }^{11}$ Deutschewitz et al. 2003; ${ }^{12}$ Pino et al. 2005;

${ }^{13}$ Kumar et al. 2006; ${ }^{14}$ Pauchard and Alaback 2004; ${ }^{15}$ Hansen and Clevenger 2005; ${ }^{16}$ Otto et al. 2014; ${ }^{17}$ Pauchard and Shea 2006.

the field data, according to the 'go with the majority rule' (De'ath and Fabricius 2000).

To check the collinearity among the predictors, the pair-wise Spearman correlation test was used. Calculations of landscape metrics and all operations on maps were conducted using Quantum GIS (Quantum GIS Development Team 2014) and SAGA GIS (Conrad et al. 2013) software. The classification tree was built using Statistica 10 software (StatSoft, Inc. 2011).

\section{Results}

In total, 309 plots were analysed (Fig. 1). In almost two thirds of them $(N=195,63 \%)$, specimens of invasive
Solidago species were found, while the remaining 114 plots (37\%) were uninvaded.

The average values and ranges of landscape characteristics and socio-economic variables at different extents are shown in Table $\mathbf{S 1}$ in the Electronic supplementary material. Most of the landscape metrics were correlated, as usually observed in landscape analysis (Uuemaa et al. 2009). In the study region, the percentage of forest cover was highly negatively correlated with the percentage of agricultural. The number of patches was correlated with the number of LC/LU classes, total length of edges and $\mathrm{H}^{\prime}$ indices. The percentage of urbanized areas was positively correlated with the length of roads and railways. Most of the correlations were found among all the buffer extents studied. The full matrix of correlations is presented in Table S2 in the Electronic Supplementary Material. 
Fig. 2 Spatial extents examined: large (buffer with a $5 \mathrm{~km}$ radius), medium ( $2 \mathrm{~km}$ radius) and small ( $0.5 \mathrm{~km}$ radius). The sizes of analysed buffers and distances between the plots are proportional to the original sampling design, but in all buffers, a landscape is shown for the same plot in order to better present the effect of changing extents on calculated landscape structure characteristics.
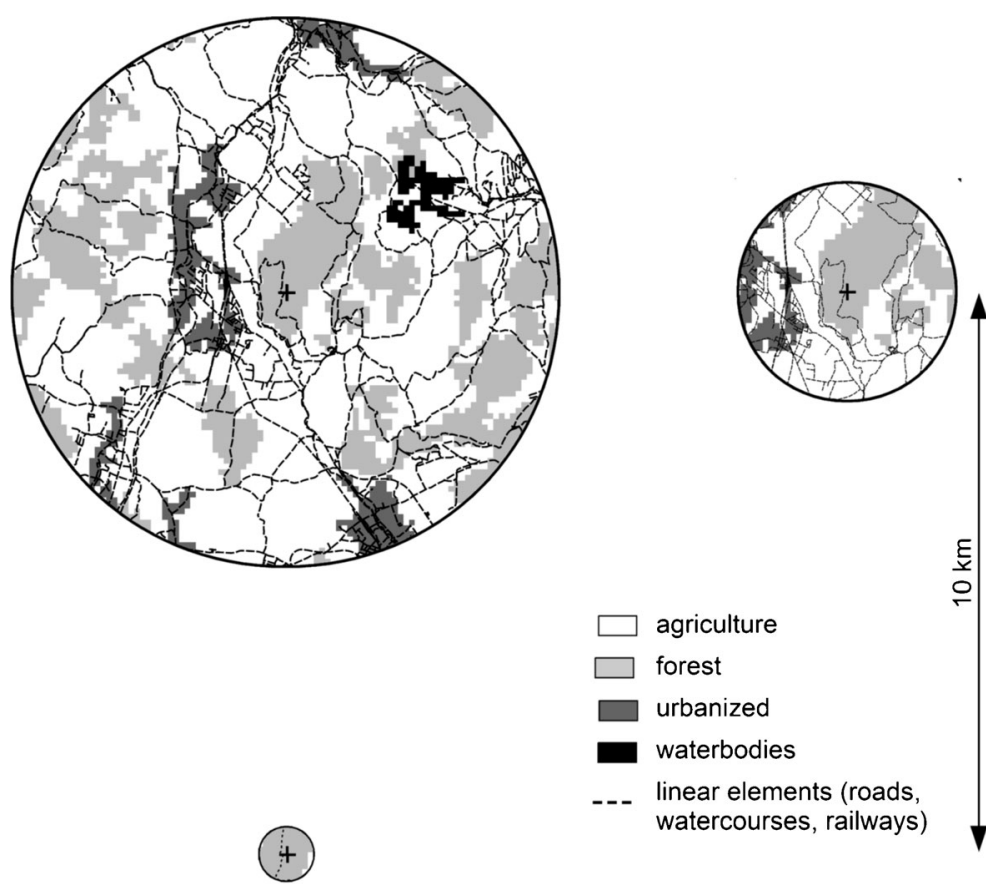

$10 \mathrm{~km}$

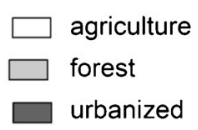

waterbodies

-. linear elements (roads, watercourses, railways)
The results of the CART analysis show that the highest accuracy of plot classification gives the percentage of forest calculated for a buffer at the small extent (radius = $500 \mathrm{~m}$ ). Plots located in pure forest were almost exclusively uninvaded (Fig. 3, group a). The length of roads at the small extent was the second predictor producing relatively pure nodes; most plots with a high-density road network were invaded by Solidago (Fig. 3, group b). Farther nodes gave less accurate, but still significant, predictions of invasion. They were created by variables operating at the large extent (radius $=5 \mathrm{~km}$ ). A group of plots with a low fraction of invaded species was separated by a very low percentage of forest cover (Fig. 3, group c). The terminal nodes were created by the percentage of urban areas (Fig. 3, groups $d$ and e) and human population density (Fig. 3, groups f and g). Finally, the overall model gives a misclassification rate of $21.7 \%$, compared to the rate of $36.8 \%$, assuming the proportion of uninvaded plots in the field data.

\section{Discussion}

\section{Ecological Meaning of Predictors}

The obtained results support the premise that both landscape structure and socio-economic variables explain the spatial pattern of invasion by alien Solidago species. First, two predictors (percentage of forest cover and length of roads) that gave the highest accuracy of classification have the maximum influence at the small extent. This indicates the importance of the inherent properties of particular habitat types to the invasion process (Chytrý et al. 2008b). The studied Solidago species in their native range occur mostly in open areas (Abrahamson et al. 2005). In Central Europe, alien Solidago species generally avoid a dense canopy cover (Weber 2000; Weber and Jacobs 2005; Szymura and Szymura 2011, 2013) and have only been rarely reported from forests (Weber 2000; Weber and Jacobs 2005; Priede 2008). Similarly as in these previous studies, in our study, alien Solidago species were found only sporadically in forests. Moreover, the patches of forest vegetation where the invasive species were found showed different signs of anthropogenic disturbances and an open canopy. Because the majority of the forests studied here were commercial plantations with a dense canopy cover, we considered the low probability of invasion in the forest mostly as an effect of overshading by tree canopies.

Two facts should be considered regarding the interpretation of the positive effect of road length on Solidago invasion. Firstly, the length of roads in a given 


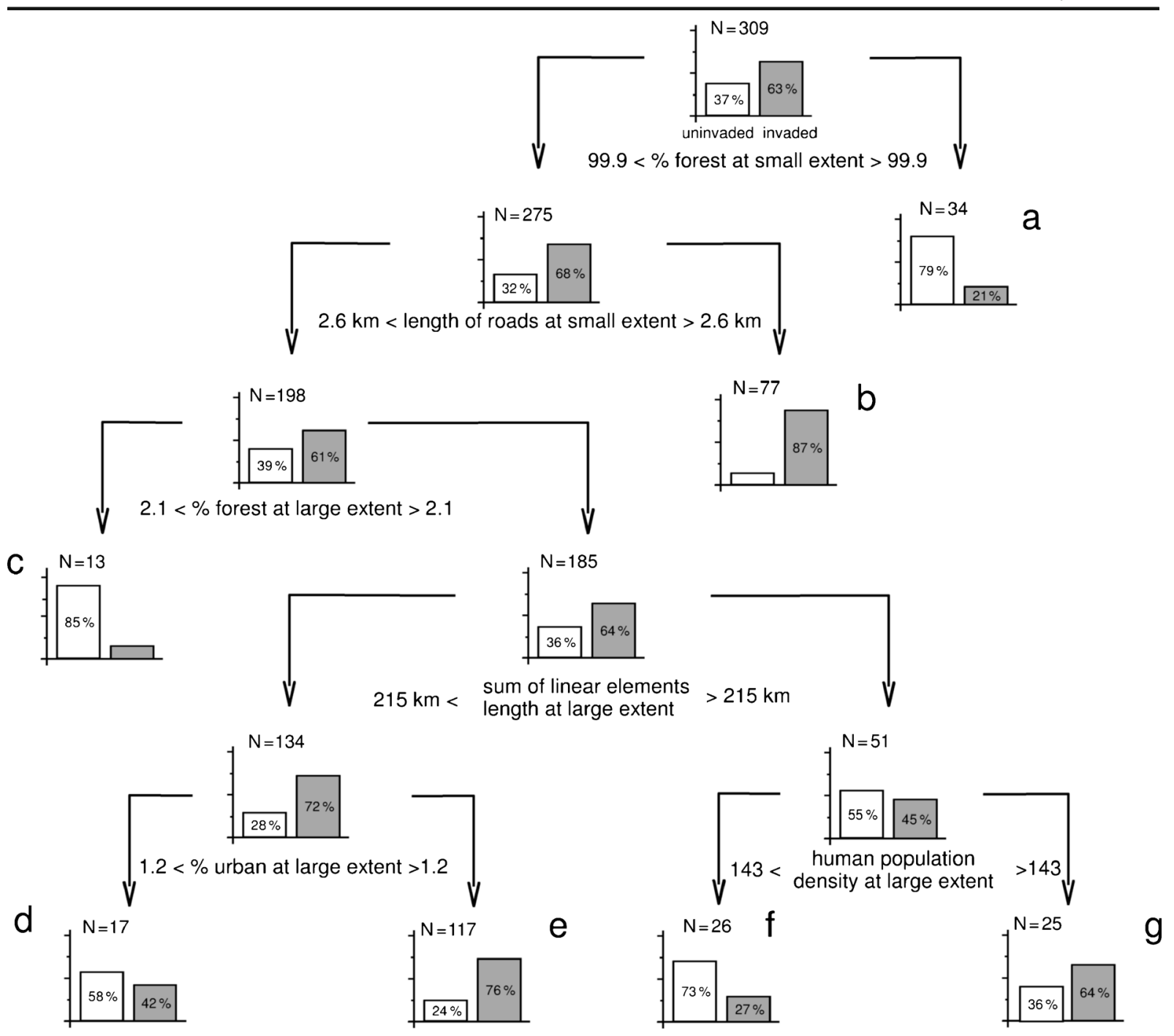

Fig. 3 Results of the classification tree model. The grey bars show the percentage of plots invaded by Solidago, while the white bars represent the percentage of uninvaded plots.

landscape unit is usually considered a proxy of increasing propagule pressure (Lonsdale 1999; Pauchard and Alaback 2004; Jørgensen and Kollmann 2009). Secondly, roadsides are a kind of specific habitat with easily available resources such as light, water and nutrients (Coffin 2007). These kinds of habitats with high amounts of unused resources are especially prone to invasion according to the fluctuating resources theory (Davis et al. 2000). Earlier studies have also found that Solidago species often occur in linear habitats such as fences and edges of different habitats (Szymura and Szymura 2011). Such strips of land, especially if not cultivated or managed, create a niche suitable for their establishment (Hansen and Clevenger 2005; Otto et al.
2014). Because Solidago species are not resistant to frequent mowing (Weber 2000; Weber and Jacobs 2005), systematic maintenance of road verges should eliminate them. However, a single cut per year does not significantly reduce shoot density, and infrequent cutting might even have the reverse effect by increasing population density in the following year (Weber and Jacobs 2005). Therefore, due to the lack of systematic management, road verges are a suitable habitat for Solidago. Indeed, in the study region, roadsides hosted about $30 \%$ of examined populations and were the second, after fallow land, preferable habitat for the invasive species. Therefore, the effect of road length should be interpreted as both reflecting propagule 
pressure and as a proxy of acreage of habitats suitable for invasion.

The interpretation of subsequent factors influencing the probability of invasion, which operate at the large spatial extent, is more complex. The low number of Solidago-invaded plots in areas with an exceptionally low percentage of forest cover at the large extent (buffer radius $5 \mathrm{~km}$ ) should not be considered an effect of lack of forest per se. The percentage of forest cover is strongly negatively correlated with the percentage of agricultural land cover (Table $\mathbf{S 1}$ in the Electronic supplemental material). Thus, we assume that plot group 'c' (Fig. 3) consists of plots situated in areas dominated by intensive agriculture located in the eastern and southeastern parts of the study region (Fig. 1). Our field observations suggest that these areas, with fertile soils, were dominated by the large-scale, intensive agriculture with an increased use of herbicides and with only a small proportion of abandoned fields. In this situation, the probability of invasion by Solidago species is low because intensive agricultural management reduces the amount of habitats suitable for invasion. Similar findings have been reported from Germany, where landscape homogenization caused by large-scale agricultural land use decreased the number of neophytes compared to more heterogeneous landscapes (Wania et al. 2006). Thus, in human-influenced landscapes on densely populated regions, agriculture could act as a buffer against invasion (González-Moreno et al. 2013; Basnou et al. 2015).

The differences in the frequency of Solidago-invaded plots in the farthest nodes of the tree (groups $d$ to g) reflected the effect of direct human influence (i.e. the level of urbanization and human population density). The final nodes, however, significantly improved the model, giving a rather low accuracy of classification (so-called purity of the node) compared with nodes placed closer to the tree root. Generally, urbanized habitats with high population density are affected by strong propagule pressure and often provide suitable habitats for alien species (Deutschewitz et al. 2003; Pino et al. 2005; Hulme 2009; Santos et al. 2011; GonzálezMoreno et al. 2014; Basnou et al. 2015). The two most common species, S. gigantea and S. canadensis, often occur in human-influenced, nutrient-rich habitats (Weber 2001; Weber and Jacobs 2005). This results in the high frequency of invaded plots in more urbanized areas (group f) and more densely inhabited (group h) plots. The observed lower frequency of Solidago- invaded plots in areas with a higher sum of linear elements length at the large extent seems to be, at first glance, inconsistent with the effects of linear habitats discussed previously. However, the classification trees are hierarchical, which means that the classification in a given node is dependent on all previous nodes (i.e. placed closer to the tree root). The group of plots with a high probability of Solidago invasion related with the high length of roads at the small extent (group 'b') was already separated (Fig. 3, group b). We therefore associated the higher frequency of Solidago-invaded plots in areas with smaller sums of linear elements length with less developed areas. In these areas, the percentage of abandoned land is higher, increasing the probability of invasion by Solidago. Within these less developed areas, however, the Solidago invasion was stronger on more urbanized land.

\section{Effect of Sampling Design on the Model}

We considered the presence or absence of the invader species a measure of invasion probability in a given landscape unit, represented by a particular plot. We did not assess the abundance of the invasive species in the field. Thus, the probability assessed in this way did not consider both abundance and the number of Solidago species invading the plot. The calculated landscape characteristics and socio-economic variables reflect the overall effect of each given variable on the presence of invaders in a plot. This approach causes uncertainty in our model. However, the sampling procedure applied allows relatively fast collection of data from large areas. Despite its simplification, it still gives an insight into the process of shaping invasion of alien species on a relatively large scale. Moreover, the landscape characteristics and socio-economic data came from publicly available resources and are relatively easy to calculate. This provides an opportunity for our established model to be used by local authorities and land managers for modelling and predicting the hazards of Solidago invasion in certain areas of interest.

Other problems are related to spatial autocorrelations. First, the probability of the presence of Solidago species at a given plot could be higher if Solidago were also present in neighbouring plots. Secondly, particular variables influencing the Solidago distribution were correlated across the analysed extents. Unfortunately, there is a lack of detailed knowledge about spatial relationships involved in the processes of Solidago invasion, 
especially about the distance of effective long-range dispersal. Thus, it is unclear whether spatially correlations will operate over the relatively large distance (10 $\mathrm{km}$ ) separating the plots under study. Moreover, the landscape structure is also spatially autocorrelated, and it is hard to distinguish whether the observed pattern results from spatial correlations in the landscape structure or the distribution of organisms under study (Mattsson et al. 2013; Fan and Myint 2014). Similarly, the effect of dependencies between particular explanatory variables calculated at different spatial extents is unclear and could potentially influence the results.

\section{Practical Implications}

In areas where the invasive species are widely distributed (area of infestation $>1,000$ ha), eradication is unlikely due to economic reasons. Populations of this species should be controlled by long-term management aimed at reducing them to the lowest feasible levels and protecting specific, highly valuable sites (Pyšek and Richardson 2008). Our results suggest that the management of alien Solidago populations at the landscape scale should focus on frequent and regular mowing of road verges. This seems to be a possible task to achieve. Greater effort should be dedicated to managing the Solidago invasion in less developed areas, which are not used for large-scale intense agriculture, as well as in densely populated and urbanized landscapes. In these cases, the invasion does not seem to be a primary result of environmental changes, but rather a symptom of socio-economic changes resulting from the abandonment farmland. Reversing this trend demands employing specific policies preventing this abandonment (Stoate et al. 2009; Navarro and Pereira 2012).

\section{Conclusions}

Landscape characteristics and the density of the human population explain the spatial pattern of the alien Solidago species invasion operating at different spatial extents. Landscape characteristics calculated at the small spatial extent provide a higher accuracy of predicting the probability of invasion, but landscape metrics and human population density at the large extent significantly improve the overall model. At the small extent, the spatial pattern of the Solidago invasion in Silesia is mostly shaped by the presence of unsuitable habitats (such as forests) and suitable habitats (such as roadsides) coupled with high propagule pressure in the latter habitat type. At the large extent, by contrast, the invasion is concentrated in less developed landscapes.

Acknowledgements The study was supported by an NCN grant (project No. N N305 401438) and grants of Wrocław University of Environmental and Life Sciences and the University of Wrocław.

Open Access This article is distributed under the terms of the Creative Commons Attribution 4.0 International License (http:// creativecommons.org/licenses/by/4.0/), which permits unrestricted use, distribution, and reproduction in any medium, provided you give appropriate credit to the original author(s) and the source, provide a link to the Creative Commons license, and indicate if changes were made.

\section{References}

Abrahamson WG, Dobley KB, Houseknecht HR, Pecone CA (2005) Ecological divergence among five co-occurring species of old-field goldenrods. Pl Ecol 177:43-56

Bartha S, Szentes S, Horváth A, Házi J, Zimmermann Z, Molnár C, Dancza I, Margóczi K, Pál RW, Purger D, Schmidt D, Óvári M, Komoly C, Sutyinszki Z, Szabó G, Csathó AI, Juhász M, Penksza K, Molnár Z (2014) Impact of midsuccessional dominant species on the diversity and progress of succession in regenerating temperate grasslands. Appl Veg Sci 17:201-213

Bartuszevige AM, Gorchov DL, Raab L (2006) The relative importance of landscape and community features in the invasion of an exotic shrub in a fragmented landscape. Ecography 29:213-222

Basnou C, Iguzquiza J, Pino J (2015) Examining the role of landscape structure and dynamics in alien plant invasion from urban Mediterranean coastal habitats. Landscape Urb Planning 136:156-164

Bornkamm R (2007) Spontaneous development of urban woody vegetation on differing soils. Flora 202:695-704

Bossard M, Feranec J, Otahel J (2000) CORINE land cover technical guide: Addendum 2000. EEA, Copenhagen.

Brabec J, Pyšek P (2000) Establishment and survival of three invasive taxa of the genus Reynoutria (Polygonaceae) in mesic mown meadows: a field experimental study. Folia Geobot 35:27-42

Bradley BA, Mustard JF (2006) Characterizing the landscape dynamics of an invasive plant and risk of invasion using remote sensing. Ecol Appl 16:1132-1147

Breiman L, Friedman JH, Olshen RA, Stone CJ (1984) Classification and regression trees. Chapmann \& Hall/CRC, Boca Raton, London, New York, Washington

Büttner G, Maucha G (2006) The thematic accuracy of CORINE land cover 2000. Assessment using LUCAS (land use/cover area frame statistical survey). EEA, Copenhagen 
Catford JA, Jansson R, Nilsson C (2009) Reducing redundancy in invasion ecology by integrating hypotheses into a single theoretical framework. Diversity \& Distrib 15:22-40

Catford JA, Vesk PA, White MD, Wintle BA (2011) Hotspots of plant invasion predicted by propagule pressure and ecosystem characteristics. Diversity \& Distrib 17:1099-1110

Chapuis-Lardy L, Vanderhoeven S, Dassonville N, Koutika LS, Meerts P (2006) Effect of the exotic invasive plant Solidago gigantea on soil phosphorus status. Biol Fertil Soils 42:481-489

Chmura D, Nejfeld P, Borowska M, Woźniak G, Nowak T, Tokarska-Guzik B (2013) The importance of land use type in Fallopia (Reynoutria) japonica invasion in the suburban environment. Polish J Ecol 61:379-384

Chytrý M, Jarosik V, Pysek P, Hajek O, Knollová I, Tichý L, Danihelka J (2008a) Separating habitat invasibility by alien plants from the actual level of invasion. Ecology 89:1541-1553

Chytrý M, Maskell LC, Pino J, Pyšek P, Vilà M, Font Smart SM (2008b) Habitat invasions by alien plants: a quantitative comparison among Mediterranean, subcontinental and oceanic regions of Europe. J Appl Ecol 45: 448-458

Chytrý M, Pyšek P, Tichý L, Knollová I, Danihelka J (2005) Invasions by alien plants in the Czech Republic: a quantitative assessment across habitats. Preslia 77:339-354

Chytrý M, Pyšek P, Wild J, Pino J, Maskell LC, Vilà M (2009) European map of alien plant invasions based on the quantitative assessment across habitats. Diversity \& Distrib 15: 98-107

Coffin AW (2007) From roadkill to road ecology: a review of the ecological effects of roads. J Transport Geogr 15:396-406

Conrad O, Bechtel B, Bock M, Dietrich H, Fischer E, Gerlitz L, Wehberg J, Wichmann V, Boehner J (2013): System for Automated Geoscientific Analyses (SAGA) v. 2.0.8. Geosci. Model Dev., 8, 1991-2007

Dajdok Z, Nowak A (2006) Solidago graminifolia (L.) Elliott in Poland-spreading and habitat preferences. In TokarskaGuzik B, Edwards K (eds) Plant Invasions. Backhuys Publishers, Leiden, The Netherlands, p 20

Davis MA, Grime JP, Thompson K (2000) Fluctuating resources in plant communities: a general theory of invasibility. $J$ Ecol 88:528-534

De'ath G, Fabricius KE (2000) Classification and regression trees: a powerful yet simple technique for ecological data analysis. Ecology 81:3178-3192

Del Fabbro C, Güsewell S, Prati D (2013) Allelopathic effects of three plant invaders on germination of native species: a field study. Biol Invas 16:1035-1042

Deutschewitz K, Lausch A, Kühn I, Klotz S (2003) Native and alien plant species richness in relation to spatial heterogeneity on a regional scale in Germany. Global Ecol Biogeogr 12: 299-311

Domaradzki K, Badowski M (2012) Possibility of chemical reduction of Solidago gigantea Aiton occurrence on fallow lands. Zesz. Nauk. UP Wroc. Rol 100:17-23

Eriksson O (2000) Seed dispersal and colonization ability of plants - assessment and implications for conservation. Folia Geobot 35:115-123

Fan C, Myint S (2014) A comparison of spatial autocorrelation indices and landscape metrics in measuring urban landscape fragmentation. Landscape Urb Planning 121: 117-128

Fenesi A, Vágási CI, Beldean M, Földesi R, Kolcsár L-P, Shapiro JT, Török E, Kovács-Hostyánszki A (2015) Solidago canadensis impacts on native plant and pollinator communities in different-aged old fields. Basic Appl Ecol 16:335-346

Fukami T, Bellingham PJ, Peltzer DA, Walker LR (2013) Nonnative plants disrupt dual promotion of native alpha and beta diversity. Folia Geobot 48:319-333

Geofabrik GmbH and OpenStreetMap Contributors 2014. Available at: http://download.geofabrik.de/europe/poland.html

González-Moreno P, Diez JM, Ibáñez I, Font X, Vilà M (2014). Plant invasions are context-dependent: multiscale effects of climate, human activity and habitat. Diversity \& Distrib 20: $720-731$

González-Moreno P, Pino J, Carreras D, Basnou C, FernándezRebollar I, Vila M (2013) Quantifying the landscape influence on plant invasions in Mediterranean coastal habitats. Landscape Ecol 28:891-903

Guzikowa M, Maycock PF (1986) The invasion and expansion of three North American species of goldenrod (Solidago canadensis L. sensu lato, S. gigantea Ait. and S. graminifolia (L.) Salisb. in Poland. Acta Soc Bot Poloniae 55:367-384

Hansen MJ, Clevenger AP (2005) The influence of disturbance and habitat on the presence of non-native plant species along transport corridors. Biol Conservation 125:249-259

Hejda M, Pyšek P, Jarošík V (2009). Impact of invasive plants on the species richness, diversity and composition of invaded communities. J Ecol 97(3):393-403

Hijmans RJ, Cameron SE, Parra JL, Jones PG, Jarvis A (2005) Very high resolution interpolated climate surfaces for global land areas. Int J Climatol 25:1965-1978

Horváth R (2012) Az agresszív gyomok terjedésének megakadályozása. In Viszló L (ed) A természetkímél"o gyepgazdálkodás: Hagyomány"orz"o szemlélet, modern eszközök. Csákvár: Pro Vértes Természetvédelmi Közalapítvány:171-188

Hulme PE (2009) Trade, transport and trouble: managing invasive species pathways in an era of globalization. J Appl Ecol 46: $10-18$

Ibáñez I, Silander Jr JA, Wilson AM, LaFleur N, Tanaka N, Tsuyama I (2009a) Multivariate forecasts of potential distributions of invasive plant species. Ecol Appl 19:359-375

Ibáñez I, Silander Jr JA, Allen JM, Treanor SA, Wilson A (2009b). Identifying hotspots for plant invasions and forecasting focal points of further spread. $J$ Appl Ecol 46:1219-1228

Jørgensen RH, Kollmann J (2009) Invasion of coastal dunes by the alien shrub Rosa rugosa is associated with roads, tracks and houses. Flora 204:289-297

Kompała-Bąba A, Bąba W, (2006) Solidago graminifolia (L.) Elliot on anthropogenic sites of the Silesian Upland (Poland). Biodivers Res Conservation 3/4:329-332

Kumar S, Stohlgren TJ, Chong GW (2006) Spatial heterogeneity influences native and nonnative plant species richness. Ecology 87:3186-3199

Lockwood JL, Cassey P, Blackburn T (2005) The role of propagule pressure in explaining species invasions. Trends Ecol Evol 20:223-228

Lonsdale M (1999) Global patterns of plant invasions and the concept of invasibility. Ecology 80:1522-1536

Marcer A, Pino J, Pons X, Brotons L (2012) Modelling invasive alien species distributions from digital biodiversity atlases. Model upscaling as a means of reconciling data at different scales. Diversity \& Distrib 18:1177-1189 
Mattsson BJ, Zipkin EF, Gardner B, Blank PJ, Sauer JR, Royle JA (2013) Explaining local-scale species distributions: relative contributions of spatial autocorrelation and landscape heterogeneity for an avian assemblage. PLOS ONE 8: e55097

Matthews JW, Peralta AL, Soni A, Baldwin P, Kent AD, Endress AG (2009) Local and landscape correlates of non-native species invasion in restored wetlands. Ecography 32:10311039

Milbau A, Stout JC, Graae BJ, Nijs I (2009) A hierarchical framework for integrating invasibility experiments incorporating different factors and spatial scales. Biol Invas 11:941950

Moroń D, Lenda M, Skórka P, Szentgyörgyi H, Settele J, Woyciechowski M (2009) Wild pollinator communities are negatively affected by invasion of alien goldenrods in grassland landscapes. Biol Conservation 142:1322-1332

Navarro LM, Pereira HM (2012) Rewilding abandoned landscapes in Europe. Ecosystems, 15:900-912

Ohlemüller R, Walker S, Bastow WJ (2006) Local vs regional factors as determinants of the invasibility of indigenous forest fragments by alien plant species. Oikos 112:493-501

Orłowski G (2005) Endangered and declining bird species of abandoned farmland in south-western Poland. Agric EcoSyst Environm 111:231-236

Otto R, Arteaga MA, Delgado JD, Arévalo JR, Blandino C, Fernández-Palacios JM (2014) Road edge effect and elevation patterns of native and alien plants on an oceanic island (Tenerife, Canary Islands). Folia Geobot 49:65-82

Ozinga WA, Hennekens SM, Schaminée JHJ, Bekker RM, Prinzing A, Bonn S, Poschlod P Tackenberg O, Thompson K, Bakker JP, van Groenendael JM (2005) Assessing the relative importance of dispersal in plant communities using an ecoinformatics approach. Folia Geobot 40:53-67

Pauchard A, Alaback PB (2004) Influence of elevation, land use, and landscape context on patterns of alien plant invasions along roadsides in protected areas of South-Central Chile. Conservation Biol 18:238-248

Pauchard A, Alaback PB (2006) Edge type defines alien plant species invasions along Pinus contorta burned, highway and clearcut forest edges. Forest Ecol Managem 223:327-335

Pauchard A, Shea K (2006) Integrating the study of non-native plant invasions across spatial scales. Biol Invas 8:399-413

Pejchar L, Mooney HA (2009) Invasive species, ecosystem services and human well-being. Trends Ecol Evol 24:497-504

Pino J, Font X, Carbo J, Jové M, Pallares L (2005) Large-scale correlates of alien plant invasion in Catalonia (NE of Spain). Biol Conservation 122:339-350

Priede A (2008) Invasive non-native Solidago species in Latvia: expansion history and current distribution. Proc Latv Acad Sci, B 62:78-83

Pyšek P (1998) Alien and native species in Central European urban floras: a quantitative comparison. J Biogeogr 25: $155-163$

Pyšek P, Sádlo J, Mandák B (2002) Catalogue of alien plants of the Czech Republic. Preslia 74:97-186.

Pyšek P, Jarošík V, Hulme PE, Kühn I, Wild J, Arianoutsou M, Bacher S, Chiron F, Didžiulis V, Essl F, Genovesi P, Gherardi F, Hejda M, Kark S, Lambdon PW, Desprez-Loustau ML, Nentwig W, Pergl J, Poboljšaj K, Rabitsch W, Roques A, Roy DB, Shirley S, Solarz W, Vilà M, Winter W (2010) Disentangling the role of environmental and human pressures on biological invasions across Europe. Proc Natl Acad Sci USA 107:12157-12162

Pyšek P, Richardson DM (2008) Invasive plants. In Jørgensen SE, Fath BD (eds) Ecological Engineering. Encyclopedia of Ecology 3, Oxford, Elsevier pp 2011-2020

Pyšek P, Richardson DM (2010) Invasive species, environmental change and management, and health. Annual Rev Environm Resources 35:25-55

Quantum GIS Development Team (2014) Quantum GIS Geographic Information System. Open Source Geospatial Foundation Project. Available at: http://qgis.osgeo.org

Ripley BD (1996) Pattern recognition and neural networks. Cambridge: Cambridge University Press

Rothmaler W (2007) Exkursionsflora von Deutschland. Band 3. Elsevier, Spektrum Akademischer Verlag, München [in German]

Rutkowski L (2013) Klucz do oznaczania roślin naczyniowych Polski niżowej. PWN, Warszawa (in Polish).

Santos M, Freitas R, Crespí AL, Hughes SJ, Cabral JA (2011) Predicting trends of invasive plants richness using local socio-economic data: an application in North Portugal. Environm Resources 111:960-966

Scharfy D, Güsewell S, Gessner MO, Venterink HO (2010) Invasion of Solidago gigantea in contrasting experimental plant communities: effects on soil microbes, nutrients and plant-soil feedbacks. $J$ Ecol 98:1379-1388

Scharfy D, Eggenschwiler H, Venterink HO, Edwards PJ, Güsewell S (2009) The invasive alien plant species Solidago gigantea alters ecosystem properties across habitats with differing fertility. $J$ Veg Sci 20:1072-1085

Schmid B, Puttick GM, Burgess KH, Bazzaz FA (1988) Correlations between genet architecture and some life history features in three species of Solidago. Oecologia 75:459-464

Semple JC, Brammall RA, Chmielewski J (1981) Chromosome numbers of goldenrods, Euthamia and Solidago (Compositae-Asteraceae). Canad J Bot 59:1167-1173

Semple JC, Ringius GS, Leeder C, Morton G (1984) Chromosome numbers of goldenrods, Euthamia and Solidago (Compositae-Asteraceae). II Additional counts with comments on cytogeography. Brittonia 36:280-292

Semple JC, Cook RE (2006) Solidago. In North America Editorial Committee (eds). Flora of North America, Oxford University Press, Oxford, pp:107-166

Shea K, Chesson P (2002) Community ecology theory as a framework for biological invasions. Trends Ecol Evol 17:170-176

Sheppard AW, Shaw RH, Sforza R (2006) Top 20 environmental weeds for classical biological control in Europe: a review of opportunities, regulations and other barriers to adoption. Weed Res 46:93-117

Simberloff D, Martin JL, Genovesi P, Maris V, Wardle DA, Aronson J, Courchamp F, Galil B, García-Berthou E, Pascal M, Pyšek P, Sousa R, Tabacchi E, Vila M (2013) Impacts of biological invasions: what's what and the way forward. Trends Ecol Evol 28:58-66

Sîrbu C, Oprea A, Samuil C, Tănase C (2012) Neophyte invasion in Moldavia (eastern Romania) in different habitat types. Folia Geobot 47:215-229

Skórka P, Lenda M, Tryjanowski P (2010) Invasive alien goldenrods negatively affect grassland bird communities in Eastern Europe. Biol Conservation 143:856-861 
StatSoft, Inc. (2011) STATISTICA (data analysis software system), version 10. Available at: www.statsoft.com

Stoate C, Báldi A, Beja P, Boatman ND, Herzon I, van Doorn A, De Snoo GR, Rakosy L, Ramwell C (2009) Ecological impacts of early 21 st century agricultural change in Europe-a review. J Environm Managem 91:22-46

Szymura M, Szymura TH (2011) Distribution of goldenrods (Solidago spp.) in Lower Silesia and their impact on biodiversity of invaded vegetation. Acta Bot Siles 6:195-212

Szymura M, Wolski K (2011) Leaf epidermis traits as tools to identify Solidago L. taxa in Poland. Acta Biol Cracov Ser Bot 53:38-46

Szymura M, Szymura TH (2013) Soil preferences and morphological diversity of goldenrods (Solidago L.) from southwestern Poland. Acta Soc Bot Poloniae 82:107-115

Szymura M, Szymura TH (2015) Growth, phenology, and biomass allocation of alien Solidago species in central Europe. Pl Spec Biol 30:245-256

Thiele J, Kollmann J, Andersen UR (2009) Ecological and socioeconomic correlates of plant invasions in Denmark: the utility of environmental assessment data. Ambio 38:89-94

Thuiller W, Richardson DM, Pyšek P, Midgley GF, Hughes GO, Rouget M (2005) Niche-based modelling as a tool for predicting the risk of alien plant invasions at a global scale. Global Change Biol 11:2234-2250

Tokarska-Guzik B (2001) The history of studies of invasive alien plants in Poland. In Tokarska-Guzik B, Brundu G, Brock J, Camarda I, Child L, Wade M (eds) Plant invasions: species ecology and ecosystem management 245-254

Uuemaa E, Antrop M, Roosaare J, Marja R, Mander Ü (2009) Landscape Metrics and Indices: An Overview of Their Use in Landscape Research. Living Rev Landscape Res 3. Available at: http://www.livingreviews.org/lrlr-2009-1

Vanderhoeven S, Dassonville N, Meerts P (2005) Increased topsoil mineral nutrient concentrations under exotic invasive plants in Belgium. Pl \& Soil 275:169-179

Vanderhoeven S, Dassonville N, Chapuis-Lardy L, Hayez M, Meerts P (2006) Impact of the invasive alien plant Solidago gigantea on primary productivity, plant nutrient content and soil mineral nutrient concentrations. $P l \&$ Soil 286:259-268
Vilà M, Espinar JL, Hejda M, Hulme PE, Jarošík V, Maron JL, Pyšek P (2011) Ecological impacts of invasive alien plants: a meta-analysis of their effects on species, communities and ecosystems. Ecol Letters 14:702-708

Vilà M, Ibáñez I (2011) Plant invasions in the landscape. Landscape Ecol 26:461-472

Vicente J, Alves P, Randin C, Guisan A, Honrado J (2010) What drives invasibility? A multi-model inference test and spatial modelling of alien plant species richness patterns in northern Portugal. Ecography 33:1081-1092

Vicente JR, Pereira HM, Randin CF, Goncalves J, Lomba A, Alves P, Metzger J, Cezar M, Guisan A, Honrado J (2014) Environment and dispersal paths override life strategies and residence time in determining regional patterns of invasion by alien plants. Perspect Pl Ecol Evol Syst 16:1-10

Wania A, Kühn I, Klotz S (2006) Plant richness patterns in agricultural and urban landscapes in Central Germany - spatial gradients of species richness. Landscape Urb Planning 75:97-110.

Wasiłowska A (1999) Spreading of alien plant species along tourist tracks in Karkonosze Mts. Polish J Ecol 47:399-408

Weber E (1997) Morphological variation of the introduced perennial Solidago canadensis L. sensu lato (Asteraceae) in Europe. Bot J Linn Soc 123:197-210

Weber E (1998) The dynamics of plant invasions: a case study of three exotic goldenrod species (Solidago L.) in Europe. $J$ Biogeogr 25:147-154

Weber E (2000) Biological flora of Central Europe: Solidago altissima L. Flora 195:123-134

Weber E (2001) Current and potential ranges of three exotic goldenrods (Solidago) in Europe. Conservation Biol 15: 122-128

Weber E, Jacobs G (2005) Biological flora of central Europe: Solidago gigantea Aiton. Flora 200:109-118

Weber E, Schmid B (1998) Latitudinal population differentiation in two species of Solidago (Asteraceae) introduced into Europe. Amer J Bot 85:1110-1121

Westphal MI, Browne M, MacKinnon K, Noble I (2008) The link between international trade and the global distribution of invasive alien species. Biol Invas 10:391-398 